\title{
A TYPE OF MINIMAL PHRASEOLOGICAL UNITS CHARACTERISTIC OF SLOVENE
}

\section{Introduction}

The Slovene language abounds with phraseological units with the structure verb and clitics (clitic word forms) jo, ga, jih, such as ucvreti jo 'to run away', lomiti ga 'to do foolish things, to make mistakes'. The linguistic treatment of this group is interesting, since the question whether $j o, g a, j i h$ are clitics of a personal pronoun or free verb morphemes raises the problem of the demarcation line between the (idiomatic) word and (phraseological) word combination. As far as phraseology is concerned, the above-mentioned group is interesting because it represents one of the structures of minimal phraseological units ${ }^{1}$ which are, doubtlessly, most frequent in Slovene second only to phraseological prepositional phrases. For the Slovene phraseology, this group is important, since it is a large one, and as examples in the Corpus of Slovene Texts called FIDA $^{2}$ show, (still) a productive one. Examples of phraseological units of the same type which are constantly formed anew lead us to believe that we are faced with a model formation and they are indicative of the processes of 'modelization'. A quick look at the phraseology of other Slavonic languages reveals that such phraseological units exist only exceptionally if they are not absent altogether. As far as I know, the phraseological units of this type exist only in Croatian and Serbian (in a very limited number of cases, such as jebi ga). In Pleteršnik's Slovene-German Dictionary (1894: 828) a note is included under the entry 1 . on (ona, ono) :

"- acc. f. sing. "jo" izraža nekak nedoločen objekt pri mnogih glagolih; potegniti jo kam, uganiti jo; Štirje jo godejo, Eden jo trobi, Npes-K.; (menda po vplivu italijanščine; prim. capirla, Mik. V. G. IV. 3o.) « ["jo" expresses an indefinite object in combination with many verbs ... (probably under the influence of Italian; cf. capirla, Mik. V. G. IV. 3o.)]

The above-mentioned facts can lead to several conclusions: this type of phraseological units was productive as early as the $19^{\text {th }}$ century and it was regarded as nonSlovene - at least the part with the component jo. The influence of Italian could also be the explanation for the fact that these phraseological units are almost completely non-existent in other Slavonic languages. I do not want to do research into and explain the origin of this type of phraseological units. Nevertheless, the influence of foreign languages has to be considered, since the combinations of the same type with

\footnotetext{
1 The term minimal phraseological unit refers to the phraseological units that are phonetic words, which means that they contain one single stressed component, whereas the other element is clitic. The latter is most frequently a preposition (na moć 'very', na lepem 'suddenly, unexpectedly', biti ob 'to lose, to not have any longer').

2 http: \\www.fida.net
} 
$g a$ and jih are present (cf. 3.2.1 the connection between lomiti ga and norec lomi koga from Gutsmann). Last but not least, even if this type of phraseological units was or had been initiated by foreign languages, it is a typical feature of Slovene to generate it (cf. also footnote 4).

1.1 Since the phraseological units of this type are obviously used almost exclusively in Slovene, the examples of how they are used in context (taken from the Corpus of Slovene Texts, called FIDA) are listed below :

$(1)^{3}$

- Vojnega ministra so likvidirali v njegovem uradu; krvavi cesar jo je že drugič popihal; rdeči Dunaj pod vodstvom mestnega komandanta (...) je pokazal voljo, da se osamosvoji.

- K. je znan kot trd poslovnež, z zastrašujočim cinizmom v stikih s partnerji in sodelavci. Zaradi ločitve od žene, ki jo je popihala $z$ mlajšim, je tudi zagrenjen.

(2)

- A če ga bo Ferrari tudi v nadaljevanju prvenstva tako lomil, kot ga je tokrat v Avstraliji, se McLarnu ne bo treba kdo ve kako truditi za naslov.

- Vse več mladih Japoncev se ne zna dobro izražati v maternem jeziku. Odrasli pogosto niso veliko boljši, lomijo ga celo politiki. Tako hudo, da je premier Keizo Obuči samega sebe kritično označil za "bokya-hin", kar pomeni nekaj takega kot človek brez besednega zaklada.

- S kronanimi glavami so težave, saj jim oblast, ki jim je kakorkoli že dana, rada premočno zleze $v$ glavo in potem ga oblastniki vseh vrst hudo kronajo, kot se v ljudskem izražanju reče, če kdo počenja neumnosti in lahkomiselnosti. ${ }^{4}$

(3)

- Vaški župnik je povabil na kosilo svojega kolega, župnika iz sosednje fare. Počasi sta obedovala in ga cukala ter se pogovarjala o vseh mogočih zadevah.

- "Ah, to je naredila pijača!" je zamahnila z roko. "Žingali smo ga kar čez mero."

- Najbolj frišnata zgodba v mestu je tista o bratu Marjanu, ki se ga je v noči na Ljubljanici nakresal, nato pa sedel $v$ avto in zgrožen opazil, da so mu nepridipravi pobrali dobesedno vse:

- Z nekakšnim mračnim zadoščenjem se je odločil, da se ga bo danes pošteno nacedil.

${ }^{3}$ Consecutive numbers in brackets refer to the semantic groups listed under 2.2.1.

4 The underlined part of the text explains one of the pragmatic instructions for the use of a phraseological unit. The fact that they are explicitly of folk character makes us believe that this type of fixed expressions is, to a certain extent, typically Slovene. 
(4)

- V centru se jim nihče ne upa postaviti po robu, zato so njihovi člani tam popolnoma varni. $\breve{C}$ pa jïh že kdo od njih stakne, je za maščvanje v trenutku pripravljenih 40 fantov.

(5)

- Zadeva je na prvi pogled zelo podobna Slovencem znani nejedrski pobudi, le da je zaradi velikosti in pomembnosti Nemčije še nekajkrat usodnejša. Scharping jih bo v Washingtonu zagotovo krepko slišal. Kajti že Schröder in Fischer ne bosta kar se da hitro pokopala (...).

When listing examples as well as in the further treatment, the analysis of the socalled pragmatic phraseological units that can be homonymous with a particular form of use of some verbal phraseological units of this type is intentionally left out. Regarding the origin the pragmatic phraseological units are most certainly connected with verbal phraseological units of this type. Note: the answer to the question $A$ veš, da je našega soseda zapustila žena? can be Ne ga lomit(i) or Ne lomi(te) ga!, both of which express extreme surprise. These two types of phraseological units should, therefore, always be treated separately. ${ }^{5}$

\section{Formal and semantic characteristics}

2.1 Morphological and syntactic characteristics

\subsubsection{Structure}

We are dealing with verbal phraseological units which perform the function of the predicator in the sentence. As "phraseological verbs", they can externally be transitive or intransitive, depending on the fact which semantic class they belong to: as verbs of motion they are intransitive (ucvreti jo), as verbs of speaking they are transitive (soliti jih komu).

The internal structure of these word combinations is filled with a transitive verb and clitics jo, ga or jih.

The verbs can be systemically transitive or transitive in this particular collocation (model). The examples of systemically transitive verbs are pobrisati $+\mathrm{N} 4$, where pobrisati jo is syntactically the same as pobrisati mizo ${ }^{6}$, or kronati $+\mathrm{N} 4$, where kronati $\mathrm{g} a$ is the same as kronati prestolonaslednika. The transitivity in one particular collocation can be observed in two cases:

\footnotetext{
${ }^{5}$ In Croatian (and as far as I know also in Serbian), the structure of the type verb+jo, ga, jih seems to be limited primarily (but probably not exclusively) to such pragmatic phraseological units. Cf. Croatian jebi ga, fučkaj $g a$ - oral communication with Ž. Fink.

${ }^{6}$ This structural sameness is the basis of a well-known Slovene joke: Po kosilu reče mož svoji ženi: "Prav, ti boš posodo pomila, jaz jo bom pa pobrisal," in odide skozi vrata. This is the actualization of the ambivalence between pobrisati posodo, where pobrisati means 'to make something dry, clean, especially with cloth' (kaj is filled with posoda 'dishes used for the preparation of and serving food'), and the phraseological unit pobrisati jo meaning 'to leave, to escape'.
} 
a) when the verb - except in this phraseological unit - is intransitive, e.g. odkuriti and odkuriti jo (in the same sense),

b) when the collocability with $j o, g a$, $j i h$ is the only acceptable and obligatory structure and the verbs in Slovene do not exist at all without this component element, e.g. *primahati, *podurhati, *ucvreti, *posvirati.

I call it model monocollocability because it is a result of functioning of the phraseological model and not the valency of the verb itself (more about this topic, see 3.2).

The clitics $j o, g a, j i h$ is used in the case required by a particular transitive verb and in verbs that are transitive in one particular collocation in the case required by the appropriate model (popihati $+j o$, kronati $+g a$, cukati $+g a$, slišati $+j i h$ ). In most cases this is the accusative, except in the type where the accusative is already occupied by se (semantic group (3) nacediti se ga - cf. 2.2.1), therefore $g a$ is in the genitive. In grammatical number the form is bound to the potential reference and in this connection to the semantic group which it belongs to (cf. 2.2.1): it appears in the singular (jo, ga) and in the plural (jih); in individual cases from group (4) it is indistinctively variant (fasati/iztakniti/stakniti/izkupiti/skupiti jo/jih). In grammatical gender the male form $g a$ prevails over the femal one $j o$ and the plural form jih, and it is like the number - bound to the semantic group. It should, however, be mentioned that in groups (1) and (2) there is an obvious link between the gender form and the semantic type, i.e. jo is bound to type (1) and $g a$ to type (2), in other words $x$-ati jo (1) 'to move ...' and $x$-ati ga (2) 'to do foolish things'.

\subsubsection{Morphological and syntactic restrictions}

No syntactic transformation is possible. Other forms which the phraseological unit uses to adapt to the context are regular: the grammatical person $(\mathrm{jaz} / \mathrm{ti} / \mathrm{on}$... ga lomi), number (midva/vi ... ga lomite), tense (sem ga lomil, ga bodo lomili ...). The formation of modal forms is also regular (lomili bi ga, ucvri jo). In some groups word combinations seem to be used only in the negative imperative, but this is of pragmatic rather than structural character. The unusual character of the non-negated form lomi ga in comparison to the more common negated form ne lomi ga is a consequence of the (pragmatic) fact that the socially negative deeds are usually not dictated or demanded; rather, they are forbidden and consequently, the form of the non-negated lexical item in the example Ti ga kar lomi! has a pragmatic function expressing warning or prohibition. ${ }^{8}$ The complements that are not elements of phraseological units are formally unlimited, they are, however, limited only semantically and pragmatically (e.g. *miza jo je ucvrla or *riba ga cuka).

\footnotetext{
${ }^{7}$ It is, therefore, possible to understand what the title of the newspaper article (Delo, 7/2-2005, p. 13) Mi ga pa timssamo wants to express: we do something wrong. It is the context that offers an explanation for the meaning of the neologism timssati - it is connected with Timss research into the knowledge of natural sciences and mathematics.

${ }^{8}$ In the Fida corpus, the examples of use lomiti ga do not include any non-negated imperative.
} 


\subsection{Meaning}

\subsubsection{Denotative meaning}

Phraseological units of the above-mentioned type can be subdivided into five distincitive semantic groups.

(1) 'to move'

'quickly/lively' + (mostly) 'secretly, inconspicuously'

brisati jo (pobrisati jo, pribrisati jo, ubrisati jo, zbrisati jo), cediti jo (pocediti jo, ucediti jo), cvirnati jo (odcvirnati jo, pocvirnati jo), cvreti jo (pocvreti jo, ucvreti jo/ucvirati jo), izmakniti jo, kuriti jo (odkuriti jo), odbrusiti jo, pobrusiti jo, pobirati jo/pobrati jo, pocitrati jo, podurhati jo, pofuliti jo, popihati jo (upihati jo, pihniti jo), potegniti jo, prasniti jo, prikaditi jo, rezati jo (urezati jo), risati jo, sekati jo (usekati jo, prisekati jo), stisniti jo, ubirati jo/ubrati jo, udariti jo, udreti jo, uliti jo, unesti jo, ustriči jo, užgati jo;

'on foot'

kresati jo/kresniti jo (prikresati jo), mahati jo/mahniti jo (odmahati jo, primahati jo), mazati jo, praskati jo, tolči jo;

(2) 'to do foolish things, careless things', 'to make mistakes'

biksati ga, biti ga, fiksati ga, kidati ga (pokidati ga/jo), kronati ga (pokronati ga), lomiti ga (polomiti ga), pihniti ga, srati ga (posrati ga/jo, zasrati ga), sračkati ga (posračkati ga), sekati ga, sekljati ga, svirati ga (posvirati ga), žingati ga;

'to cause troubles/inconveniences/problems'

gosti jih (zagosti jo, nagosti jo), nagoditi jo, napresti jo, našpičiti jih (komu);

(3) 'to drink alcoholic drinks, to get drunk', 'to be a drunkard', 'to be drunk'

piti ga, cukati ga, lokati ga (polokati ga), luckati ga, pokončati ga, rukniti ga, srebati ga/srebniti ga, srkati ga/srkniti ga (posrkniti ga), suniti ga, usušiti ga, vleči ga, zdelati ga, zvračati ga, žehtati ga, žreti ga

'to be drunk'

čutiti ga, imeti ga, nabrati se ga, nabrenkati se ga, nacediti se ga, nacukati se ga, nakresati se ga, nalesti se ga, nalokati se ga, naložiti si ga, naluckati se ga, napiti se ga, nasekati se ga, natreskati se ga, natrkati se ga, nazobati se ga, napiti se ga, nasrkati se ga, nažehtati se ga, nažreti se ga; nesti ga;

(4) 'to deliver blows, to hit'; 'to get blows', 'to be punished'

'to hit'

dati jih, naložiti jih, namazati jih, nametati jih (komu), primazati jo/jih;

'to get blows'

dobiti jih/dobivati jih, fasati jo/jih, iz-/skupiti jo/jih, iz-/stakniti jo/jih;

\footnotetext{
${ }^{9}$ This information is important for the connotative part of the meaning, since the negative implication of getting away from a place (escape!) is most probably the reason for euphemization.
} 
(5) 'to speak angrily'

'to reprimand, to scold'

beliti jih, napeti jih, napovedati jih, naštevati jih, natrobiti jih, robiti jih, soliti jih/zasoliti jo (komu);

'to be reprimanded, to be scolded'

dobiti jih, slišati jih.

Groups (4) and (5) could be joined into one semantic group 'to attack (physically or verbally)' or 'be (physically or verbally) attacked'.

\subsubsection{Connotative meaning}

The phraseological units discussed above have a high degree of expressiveness that originates primarily from their euphemization. The use of these expressions makes a negatively evaluated deed (especially if it is negatively evaluated from the social point of view) milder: escape out of fear, drunkenness, negative speaking, hitting. The verbal component can be marked for register in advance, i.e. when the component is marked for register when it is used outside the phraseological unit, thus contributing an additional connotation, especially the label vulgar, e.g. srati in srati $g a$, or informal, e.g. žreti in žreti ga. The expressiveness is partially connected with a partial limitation of a great number of such units to speech (not writing), which is a kind of restriction as regards language variety, but as the example unter (2) in 1.1 (cf. also footnote 4) shows explicitly, it also exerts influence on the connotative part of the meaning.

\subsubsection{Idiomaticity}

The degree of idiomaticity differs from seeming semantic predictability, i.e. motivatedness (piti ga 'to be a drunkard' < to drink alcohol) ${ }^{10}$ via partial motivatedness (metaphorical transference: naložiti jih /komu/ < to deliver blows) to complete idiomaticity and unmotivatedness (usekati jo, lomiti ga $<$ ???). The borderline between complete and partial idiomaticity runs between the semantic groups (2) and (3), so that the phraseological units in groups (1) and (2) are completely unmotivated, whereas the word combinations in other groups have a partially motivated meaning. In groups (1) and (2), a suitable reference which the component elements jo and $g a$ would refer to cannot be thought of (synchronically). It is, however, possible to claim that a kind of specialization was established as distinctive, namely jo meaning to move fast' and $g a$ meaning 'to do foolish things'. This can clearly be illustrated by

10 In group (3) some phraseological units have the smallest degree of idiomaticity. If, however, examples for a (free) referential function ga (e.g. Alkohol je zelo nevaren, če ga pijemo istočasno z jemanjem zdravil or Natočila si je malo soka in ga začela piti $z$ dolgimi požirki) can be found in the Fida corpus for a simultaneous occurrence of the verb piti and ga besides the phraseological realization (e.g. Vožji izbor so prišli še oglasi "Slovenci ga radi pijemo" naročnika Ljubljanske mlekarne /.../, we can establish that the simultaneous occurrence of napiti se and $g a$ always represents a textual realization of a phraseological unit. 
examples where jo and $g a$ are semantically distinctive component elements: pihniti jo, sekati jo in group (1) and pihniti ga, sekati ga in group (2). This tendency is further confirmed by the phraseological units - still included in the Slovar slovenskega knjižnega jezika (Dictionary of the Slovene Standard Language - hereafter called SSKJ) - which contain the variant (that is semantically indistinctive) component element jo/ga, e.g. posrati ga/jo, pokidati ga/jo. With these phraseological units the modern variant with $g a$ has become prevalent (possibly even the only possibility), since the meaning 'is to make foolish thing', and consequently, they can be put into group (2). ${ }^{11}$

\section{Model tendency}

\subsection{Neologisms}

If we compare the material included in the SSKJ with the material included in older Slovene dictionaries and the more contemporary material appearing after 1990, when the last part of the SSKJ was published, we can find out that the number of phraseological units with the discussed structure increases with time.

\subsubsection{Historical perspective}

Two Slovene dictionaries published in the $19^{\text {th }}$ century reveal that as far as the quantity is concerned, the phraseological units of this type were significantly fewer in number. In Murko's Slovensko-nemški in nemško slovenski ročni besednik (Slovene-German and German-Slovene Dictionary; Murko 1832, 1833) they are not to be found; only two sentential phraseological units with the component jo or ga are listed, namely sam Bog jo ve, bodi ga Bog zahvaljen (Gott sei Dank). ${ }^{12}$ In Pleteršnik's Slovensko nemški slovar (Slovene-German Dictionary; 1894/95), it is already possible to find four out of five semantic groups, but the number of phraseological units included in them is limited; it is, therefore, possible to list all of them:

(1)

brisati jo (pobrisati jo), cediti jo, cvreti jo (pocvreti jo), mahati jo/mahniti jo (primahati jo), potegniti jo, prasniti.jo, rezati jo (urezati jo), ubrisati jo, udreti jo, uliti jo, unesti jo, upihati jo, usekati jo (prisekati jo), ustriči jo;

(2) -

11 Since the Fida corpus contains written texts, it is deficient if we want to prove things of this kind. In spite of that all the examples included in the corpus confirm the above-mentioned propositions, i.e. for the first one: pihniti ga -10 occurrences all meaning 'to do foolish things', sekati jo -2 occurrences meaning 'to move /.../', pihniti jo - 1 occurrence meaning 'to move /.../'; for the second one: posrati ga -8 occurrences (there is no example with jo), pokidati ga - 1 occurrence (there is no example with $j o$ ).

12 Although they are not of the same type, they are worth mentioning, since they show variability and a certain degree of instability of the pronominal component in phraseology. Today, $g a(B o g / s i / g a$ vedi) is used in sam Bog jo ve, whereas bodi ga Bog zahvalien is used without the pronominal component in Bog bodi zahvaljen. 
(3)

žehtati ga; nabrenkati se ga, nalesti se ga, naliti se ga, napiti se ga, natrkati se ga, navleči se ga, imeti ga (pod kapo);

(4)

naložiti jih (komu), izkupiti jih/jo;

(5)

napeti jih (komu).

The above examples show that also Pleteršnik's dictionary lacks the phraseological units belonging to group (2) of the type lomiti ga 'to do stupid things, to make mistakes'. This type can be found as late as Glonar's Dictionary of the Slovene Language (1936), where it is explained in a quite unusual way: under the entry lomiti one can find at the end of this entry (where Glonar's dictionary normally includes phraseological units) - besides lomiti ga and the sense "to attract attention with odd behaviour' - the following: to vino ga pihne, lomi in markira without the explanation and under the entry pihniti one can find pihniti ga: gl[ej] lomiti ga.

On the basis of the situation found in the dictionaries, it is, by no means, possible to conclude that everything included in the SSKJ is new, i.e. formed as late as the 20th century. At least to a certain extent, the absence of phraseological units of this type in older dictionaries and the absence of some of them also in the SSKJ can be explained by the fact that they are restricted primarily to spoken language (i.e. they do not appear in written language), partially even to colloquial language (cf. 2.2.2).

\subsubsection{New material}

Neologisms obviously formed according to a model can be found in the FIDA corpus, which contains Slovene texts originating primarily from the second half of the 1990s. Examples classified according to semantic groups show the following picture:

(1)

Po treh urah rahlo dolgočasne vožnje - ker če šlepaš prikolico, je bolje ne pritiskati na gas - sem prispel $v$ Vrsar in jo picil direktno $v$ nudo kamp na Koversado. Iz ene sredine $v$ total drugo.

(2)

Ona se je poročila s Hughem, z nïm sem ga svoje časa precej žural skupaj po Newcastlu. Menda sta zelo srečen par.

(3)

Zadnjič je imela naša firma svoj vsakoletni jesenski piknik, krasna lokacija pod Alpami. Na koncu smo se ga tako natrobili, da je Brian (...) telebnil na cesto in mu je neki avto skoraj zapeljal čez glavo.

Extension of the meaning 'to take drugs': 
"Kaj se pa greš?” sem čisto nepričakovano eksplodiral. "(..) O čem pa govoriš? Si zadrogirana? Se ga zadevate na tisti vaši kurčevi konferenci?" - "Ne, Duane, ne zadevamo se," je rekla.

Generalization of the meaning: 'to take socially unacceptable drugs':

Pijanci, ki se ga zadevajo po oštarijah, b rad, dab bli tudi vsi okrog njih tolk zadeti ko oni, tapravim džankijem pa se totalno jebe za vse naokrog.

(4)

Strban razlaga, kako se je precej podjetij prepozno lotilo sanacije. Nekateri so se rešili že več kot polovice delavcev, ko so ugotovili, da jih imajo še vedno pol preveč. Tisti, ki so se zadnji lotili reševanja, so ga najbolj nasrkali. So v blokadi, ker imajo večinoma zaščitene delavce, sindikalne zaupnike, delavce z nezaposlenimi družinskimi člani in invalide (...).

Zvonar: "Kakorkoli obrneš, si ga najebal.«

(5) -

I failed to find examples for the semantic group (5) in the corpus, which does not necessarily mean that they do not exist in Slovene. The above-mentioned neologisms show that the groups of phraseological units discussed are formed according to a certain model. Five out of six 'new phraseological units' (pičiti jo, žurati ga, zadevati se ga and nasrkati ga, najebati $g a$ ) are combinations of verbs that themselves have the same meaning as the phraseological unit (piciti 'to head for, to go somewhere /quick$1 \mathrm{y} /{ }^{\prime},{ }^{13}$ zurati 'to have fun, to do foolish things', nasrkati, najebati 'to be punished') and the component element $j o, g a$, which harmonizes the word combination with the model, thus adding the connotation to it. Besides that, the word combination zadevati se ga shows an additional direction: the generalization of the meaning of semantic group (3). This group comprises the meaning 'to get drunk = to consume alcoholic drinks', the meaning of the neologism zadevati se ga is, however, first extended to the meaning 'to take drugs', then it is generalized to include the meaning 'to take (any kind) of socially unacceptable drugs'. The combination natrobiti se ga 'to be drunk' is a slightly more complicated formation, maybe a hapax. ${ }^{14}$ This is the contamination. Instead of the verb potrobiti 'to drink', which would be included in model group (3) because of the pronominal group $g a$ - like in the previous examples of neologisms - a different prefixed verb natrobiti is used. This is no coincidence, since this form already exists within the model (napiti/nacukati/navleči/nažreti se ga). However, in group (5) we come across the phraseological unit natrobiti jih (komu) 'to

13 Cf. in the Fida corpus: [...] po uspešnem prehodu meje pa pičǐ proti Benetkam, slediš kažipotu [...].

14 The Fida corpus provides 4 occurrences, but all the uses are limited to two texts written by the same author. (Cf. the number of occurrences of other neologisms in the Fida corpus: žurati ga - 11, zadevati se ga - 10, nasrkati ga -1 , najebati ga - 7.) 
scold somebody', which does not share anything with semantic group (3), except the model. If the type natrobiti se ga established itself (it may already be established in slang?), this would be the only example with semantically distinctive components ga and $j i h$ (presently, only jo and $g a$ are semantically distinctive, whereas jo and $j i h$ are variants - cf. 2.2.3).

\subsection{Modelization}

On the basis of the existence of neologisms, we can conclude that semantic groups of phraseological units of the type verb+jo, $g a$, jih are open. The way of generating new phraseological units of this type leads us to the conclusion that they have been formed according to the model. Without wanting to explore the ways of etymological development of these phraseological units, it is not difficult to trace the modelization, which contributed to the fact that such an extensive group was formed in the Slovene language, a group which is almost completely absent in other Slavonic languages. Three steps can be noticed: euphemization, shortening, uniformity of the model (in terms of form and meaning).

3.2.1 The euphemization is a consequence of substitution of the pronominal component for a full lexical word. The reason for it is a negative evaluation of the deed that is named by the (phraseological) unit: cowardly retreat, morally disputable merrymaking, and taking socially illegal drugs and uncontrolled social behaviour towards another person (physical and verbal violence). The consequence of the euphemization is a highly connotative nature of these phraseological units.

The substituted full lexical components can be reconstructed to a certain extent, at least in the very generalized sense and in some cases the phraseological units containing them as variant components still exist. According to the semantic groups they are:

(1) ubrati pot/smer $\rightarrow$ ubrati jo; (3) piti alkohol (= vino, žganje) $\rightarrow$ piti ga, (4) dati/dobiti $k l o f u t e$, udarce ... $\rightarrow$ dati jih/dobiti jih, primazati tako/eno (klofuto, zaušnico) $\rightarrow$ primazati jo; (5) slišati (hude, jezne ...) besede $\rightarrow$ slišati jih, beliti hude $\rightarrow$ beliti jih, robiti debele/kosmate/take $\rightarrow$ robiti jih, zasoliti tako/eno $\rightarrow$ zasoliti jo; soliti hude $\rightarrow$ soliti jih ${ }^{15}$

As a substituted full lexical component, the component element pot is only potential for the phraseological meaning of entire group (1) from the synchronic point of view. The SSKJ includes only an example for ubrati jo, cf. ubrati pot/smer. On the other hand, Glonar 1936, for example, lists under the entries cvreti, ucvreti and ubrisati the variants cureti jo (pot), ucvreti jo (pot) and ubrisati jo (pot) for the meaning 'to run away', 'to hurry up, to hurry away' (this probably holds true of the entire group, but Glonar's dictionary was not systematically checked).

As it can be seen, the full lexical component is unpredictable only for group (2). The only connection is partially offered by the word combination norec ga lomi with

15 The pronominalization is not recorded in the SSKJ, I have come across it in spoken language. 
the German semantic equivalent 'er ist muthwillig', which is included in all older editions of the Slovene dictionaries from Gutsman (1789) and Murko (1832) to Pleteršnik (1894/95), whereas later on it is absent -- it is not included in Glonar's dictionary (1936) let alone in the SSKJ. The word combinations are semantically not mutually exclusive, on the contrary, they support each other ${ }^{16}$. A hypothetical development of the euphemization could be established between them in the following way: norec $_{1} \operatorname{lomi}\left(\mathrm{koga}_{2}\right)^{*}\left(\mathrm{kdo}_{2}\right)$ lomi norca $\left(\mathrm{kdo}_{2}\right)$ lomi ga lomiti ga - and in this way the model could be filled. The explanation and confirmation of this hypothesis can be found in Pleteršnik's dictionary (Pleteršnik 1894/95: 828) under the above-mentioned entry word (see explanation under 1) 1. on:

»- $v$ nikalnih stavkih more genitiv tega zaimena spremljati samostalnik, katerega se tiče zanikovanje: ni ga jezika, ni je besede, Ravn.-Mik.; Ni ga lasu na glavi več, Prěs.; nimam ga človeka, ki bi me v jezero dejal, Ravn.-Mik.; tako tudi v akuzativu v vzklikih: da jo nevošcljivost! da ga napuh!«. (Underlined by $\mathrm{E} . \mathrm{K}$.) [in negative sentences the genitive of this pronoun can be followed by a noun which the negative form refers to ... similarly also in the accusative in exclamations ... $]$

As has already been mentioned (cf. 2.1.2) lomiti ga is used primarily (so to speak exclusively) in negative sentences. Consequently, it is not difficult - in reference to Pleteršnik's note - to establish the original word combination * ne lomi ga norca. It is, however, true that it has not been confirmed and found in textual material.

3.2.2 The shortening can still be traced in the following variant phraseological units:

(1) -; (2) -; (3) imeti ga (v glavi/pod kapo/pod klobukom), nabrati se ga (kot berač mraza/uši); (4) dobiti jih (po glavi/grbi ...), primazati jo (okrog ušes); (5) dobiti jih (po jeziku).

A longer variant does not exist in those two semantic groups in which there is no predictable reference at least from the synchronic point of view. This is the second criterion which divides this type of phraseological units into two parts, namely (1), (2) : (3), (4), (5).

3.2.3 Obviously, the uniformity of the model ('modelization') is possible only after the first two steps when the participation of the lexical meaning of both component elements in the entire phraseological meaning is the smallest. 'Modelization' is used to refer to the process in which analogous word combinations are formed without a prior substitution due to the euphemization and/or shortening. The originally euphemistic element $j o, g a, j i h$ in these word combinations is only an element which classifies the combinations into a certain semantic group (a1 and a2); the ver-

16 The connection is established primarily through the meaning of the translational equivalent mutwillig "wilful' - cf. SSKJ objesten 'ki zaradi velike sproščenosti, premajhnega čuta odgovornosti (rad) naredi, povzroči kaj slabega, neprimernega, navadno za šalo' [tending to cause something bad, inappropriate, usually just for fun, due to the state of being too relaxed and lacking responsibility] and the meaning of group (2) 'to do foolish things, to make mistakes'. 
bal component is also only modified from a word formational (b1) point of view as well as lexically with semantic (b2) shifts:

(a1) the component $j o, g a$, jih classifies the combination into a model, thus gaining an additional connotation:

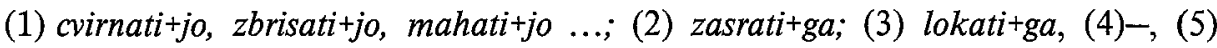
natrobiti $+j i h$;

(a2) the component without reference (in groups (1) and (2)) specializes - jo for semantic group (1) and $g a$ for semantic group (2):

(1) brusiti pete, noge (pete $=\mathrm{jih})^{17} \rightarrow$ odbrusiti jo, pobrusiti jo, stisniti rep med noge (rep=ga) $\rightarrow$ stisniti jo,

(2) posrati ga/jo, pokidati ga/jo $\rightarrow$ posrati ga, pokidati ga;

(b1) from a word formational point of view (verbs formed according to a pattern): podurhati jo $\left({ }^{*} \text { durhati }\right)^{18}$, posvirati ga $\left(\leftarrow\right.$ svirati ga; ${ }^{*}$ posvirati $)$, ucvreti jo (*ucvreti), udreti jo, uliti jo, unesti jo, sekljati ga $\leftarrow$ sekati ga, srackkati ga $\leftarrow$ srati ga;

(b2) lexically:

form (sound analogy): fiksati ga $\leftarrow$ biksati ga, (contamination): svičkati ga svirati ga + sračkati ga;

semantics (semantic transference): e.g. in group (3) 'to consume alcohol': piti, luckati, lokati, srkati, srebati; (food) nazobati se, žreti, (to turn a glass) zvrniti/zvračati, (a gesture with a hand when drinking) rukniti, suniti etc.

\section{4 (Idiomatic) word or (phraseological) word combination?}

To conclude with, I would like to return to the question posed at the beginning of this article: Are fixed expressions of the type verb $+j o, g a$, jih word combinations consisting of a verb and personal pronoun and consequently phraseological units, or are they verbs with a free morpheme, which is only homonymous with a clitic of a personal pronoun?

4.1 The argument in favour of the classification of the structure verb $+j o, g a$, jih as the word combinations is supported by two criteria: the existence of the reference and the participant role of the component $j o, g a$, jih, which can be tested by means of sentential negation. From the synchronic view the first criterion causes the combinations to fall into two categories. The fact that semantic groups from (3) to (5) belong to word combinations can be proved by the existence of the reference: (3) ga 'alcohol', (4) jo 'slap', jih 'hits, slaps', (5) jih 'words'. The second criterion used to establish the existence of syntactic relations between the verbal component and the components jo, ga, jih - J. Toporišič $(1982: 118 / 119)$ was the first one to mention this criteriontests how the negated predicator affects $j o, g a, j i h$. As a rule, sentence negation (i.e.

\footnotetext{
${ }^{17}$ This is only a seeming substitution with the component jo (cf. the meaning brusiti pete/noge 'to walk fast, to run', stisniti rep med noge 'to go away, to run away, to give up, to stop').

18 The asterisk $\left(^{\star}\right)$ implies that the verb does not exist in Slovene in such a form.
} 
the negation of the predicator) in Slovene causes the transformation of the object from the accusative to the genitive (vidim stol - ne vidim stola). If this transformation is made with the components $j o, g a, j i h$, we are dealing with a case governing word combination and the component $j o, g a$, jih is a personal pronoun functioning as the object. A test of the criterion is necessary for the combinations of semantic groups (1) and (2), i.e. those without the reference that can be synchronically determined. The transformation is provable in group (1): $j o \rightarrow j e$, since in group (2) the component $g a$ appears in the same form in the accusative as well as in the genitive. The example of use (Fida): "Kar bleknila sem, ne da bi sploh hotela kaj reči, potem pa je malo manjkalo, da je nisem kar ucvrla iz kuhinje, ko sem opazila njuna osupla obraza, ki sta me vprašujoče gledala." In texts, the transformation is not always realized, but a reason for this is a tendency of weakening of the use of this transformational rule in the Slovene language in general, especially in spoken texts. It may also be claimed that fixed expressions tend to retain the accusative even after sentential negation, which is more pronounced than in the case of free combinations. Interestingly, the SSKJ includes two examples ne boš je zvozil (the entry jo) and je ne boš odnesel (the entry odnesti), which confirm the transformation. It is, however, really surprising that the transformation is entirely confirmed by the Fida corpus: all the textual examples of the phraseological units pobrisati jo, ucvreti jo, popihati jo with sentential negation realize the transformation of the accusative into the genitive (the fact that the Fida corpus is a corpus of written not spoken texts should be taken into consideration).

4.2 At least one part of the word combinations under consideration consists of one word - those belonging to group (2), whose character of word combinations can be proved with the participation of the component $g a$ neither referentially nor syntactically - which can be proved by the uniformity of the function of jo, ga, jih and the function of the free morpheme se as the element that deprives the verb of its transitivity (Dular 1982: 149, cf. note 6), e.g. in razbiti se. The advocates of this argument keep forgetting that in phraseology one can quickly find examples where the component which is a full lexical word outside the phraseological unit deprives the verb of its transitivity. For example, in phraseological unit stegniti pete 'to die' the component pete deprives the verb stegniti of its transitivity, but the word pete is still not a free morpheme following the verb stegniti. Despite this, the task of phraseology remains to answer the question: why is stegniti se 'to die' not a phraseological unit, whereas stegniti pete 'to die' is? ${ }^{19}$

${ }^{19} \mathrm{Cf}$. stegniti pete - *stegniti svoje pete - * ${ }^{*}$ stegniti sebe - stegniti se. Similarly, e.g. odpreti svoje srce komu - odpreti se komu, opeči si prste - opeči se etc. 
Bibliography

Janez DULAR, 1982: Priglagolska vezava v slovenskem knjižnem jeziku. Doktorska disertacija. Ljubijana.

FIDA - Korpus slovenskega jezika. URL: http://www.fida.net

Joža GLONAR, 1936: Slovar slovenskega jezika. V Ljubljani.

Erika KRŽIŠNIK, 1999: Frazeologija v Murkovem slovarju. Murkov zbornik. Maribor. 312-347.

Osvald GUTSMANN, 1789: Deutsch-windisches Wörterbuch mit einer Sammlung der verdeutschten windischen

Stammwörter, und einiger vorzüglichern abstammenden Wörter. Klagenfurt.

Anton J. MURKO, 1832: Slovénsko-Némhki in Némhko-Slovénski rézhni besédnik. Graz.

Maks PLETERŠNIK,1894/95: Slovensko-nemški slovar. VLjubljani.

Slovar slovenskega knjižnega jezika (SSKJ). I. - 1970, II. - 1975, IV. - 1985, V. - 1991. Ljubljana.

Jože TOPORIŠIČ, 1982: Nova slovenska skladnja. Maribor.

\section{Povzetek \\ ZNAČILEN TIP SLOVENSKIH MINIMALNIH FRAZEMOV}

Prispevek predstavlja skupino frazemov s strukturo Glag + jo, ga, jih (ucvreti jo, lomiti ga, soliti jih), ki je jezikoslovno zanimiva, ker z vprašanjem o kategorialnem pomenu klitičnih oblik jo, ga, jih problematizira mejo med besedo in besedno zvezo. Frazeološko je to tip t. i. minimalnih frazemov, tj. frazemov $z$ eno samo polnopomensko sestavino oz. frazemov fonetičnih besed, in kot kaže, je bolj ali manj omejen na slovenski jezik (z nekaj enotami v hrvaščini in srbščini). Zanimivo je tudi, da je v slovenščini tvorba modelno produktivna, kar kažejo neologizmi (pičiti jo, žurati ga, zadevati se ga, nasrkati $g a$ ). Obravnavana skupina frazemov je predstavljena $z$ vidika oblikovnih (oblikoslovno-skladenjskih) in pomenskih lastnosti, prikazani so postopki, ki so privedli do njene "modelizacije«. Denotativnopomensko gre za pet skupin: 1. ucvreti jo, pobrisati jo 'premikati se hitro, naskrivaj'; 2. lomiti ga 'delati neumnosti, lahkomiselnosti', 'delati napake'; 3. cukati ga 'piti alkoholne pijače / opijati se', nalesti se ga, 'biti pijan(ec)', 4. naložiti jih /komu/'dajati udarce, tepsti' in skupiti jo/jih 'dobivati udarce', 'biti kaznovan', 5. soliti jih 'jezno govoriti, oštevati, zmerjati' in slišati jih 'biti oštet, ozmerjan'.

Vprašanje, ali gre pri obravnavanih zvezah za (idiomatsko) beseđo ali (frazeološko) besedno zvezo oz. ali so klitične oblike jo, ga, jih zaimkovne ali gre za proste morfeme ob glagolih, se preverja $\mathrm{z}$ dvema meriloma: $\mathrm{z}$ obstojem reference jo, ga, jih (lomiti ga = lomiti ?; cukati ga = alkohol, slišati jih $=$ besede itd.) in $\mathrm{z}$ obstojem skladenjskega razmerja med glagolom in klitiko (Ucvrl jo je. - Ni je ucvrl.). Argument, da imajo jo, ga, jih - enako kot povratni se - samo funkcijo odvzemalca prehodnosti glagolu, je relativiziran $z$ dejstvom, da imajo $v$ (glagolskih) frazemih mnoge sestavine enako funkcijo, npr. pete ob stegniti v stegniti pete 'umreti'. Nereše(va)no ostaja iz tega neposredno izvirajoče vprašanje: zakaj torej stegniti se 'umreti' ne bi bil frazem, če stegniti pete je? 